\title{
HUBUNGAN DUKUNGAN KELOMPOK SEBAYA DENGAN KUALITAS HIDUP ODHA DI YAYASAN LANTERA MINANGKABAU SUPPORT PADANG TAHUN 2016
}

\author{
Revi Neini Ikbal ${ }^{1}$, Suca Ananda Safitri ${ }^{2}$ \\ ${ }^{1}$ STIKes Alifah, Padang 25000 \\ Email: revineini@gmail.com \\ ${ }^{2}$ STIKes Alifah, Padang 25000 \\ Email: stikes_alifah@yahoo.com
}

\begin{abstract}
ABSTRAK
Penelitian ini bertujuan untuk mengetahui hubungan dukungan kelompok sebaya dengan kualitas hidup ODHA di Yayasan Lantera Minangkabau Support Padang tahun 2016

Penelitian ini bersifat analitik dengan desain cross sectional study yang telah dilaksanakan di di Yayasan Lantera Minangkabau Support Padang pada bulan Februari - Agustus 2016. Populasi seluruh ODHA di Yayasan Lantera Minangkabau Support Padang tahun 2014 yang berjumlah 805 orang. Teknik pengambilan sampel secara accidental sampling dengan jumlah sampel sebanyak 89 orang.. Hasil penelitian didapatkan 41,6\% ODHA memiliki kualias hidup yang kurang baik. Sebesar 51,7\% ODHA mendapatkan dukungan kelompok sebaya yang kurang baik. Ada hubungan dukungan kelompok sebaya (KDS) dengan kualitas hidup ODHA (p value $=0,000)$

Dapat disimpulkan bahwa dukungan kelompok sebaya berhubungan dengan kualitas hidup ODHA, maka diharapkan kepada LSM Yayasan Lantera Minangkabau untuk dapat bekerja sama dengan Dinas Sosial dalam upaya memberikan pembinaan kepada ODHA dan memberikan setiap kegiatan positif yang dapat menciptakan hubungan yang baik sesama ODHA.
\end{abstract}

Kata Kunci: Kualitas Hidup, Dukungan Kelompok Sebaya

\begin{abstract}
This research was to find out the relation between the support of the peers and the quality of life of people with HIV-AIDS at Lentera Minangkabau Support Padang 2016.

This research was analytical with cross-sectional study which had been done at Lentera Minangkabau Support Foundation Padang in February to August 2016. The populations were people living with HIV at Lentera Minangkabau Support Foundation in 2014 which 805 people. The sampling technique used was accidental sampling with 89 people as samples. From the result, it was found of that 41,6\% of people living with HIV-AIDS had poor quality of life 51,7\% of them did not get good support from their peers. There was relation between the support of the peers and quality of life of people living with HIV-AIDS ( $p$ value =0,000).

It can be concluded that the support of the peers corresponds to the quality of life of people living with HIV-AIDS. So, it is expected that Non-Govermental Organization such as Lentera Minangkabau Support Foundation cooperates with Departement of Health in an effort to provide guidance to people living with with HIV-AIDS and provide activities which can create good relationship among them.
\end{abstract}

Keywords $\quad$ : Life quality, Peer Support 


\section{PENDAHULUAN}

Penyakit global yang saat ini menyerang seluruh wilayah dunia termasuk indonesia adalah infeksi hiv/aids. Infeksi oportunistik terjadi oleh karena menurunnya daya tahan tubuh (kekebalan) yang disebabkan rusaknya sistem imun tubuh akibat infeksi hiv tersebut. acquired immune deficiency syndrome (aids) merupakan kumpulan gejala penyakit yang disebabkan oleh hiv. virus hiv ditemukan dalam cairan tubuh terutama pada darah, cairan sperma, cairan vagina dan air susu ibu (nursalam \& kurniawati, 2011).

Banyak negara besar dan berkembang lainnya terjadi permasalahan terkait HIV/AIDS. WHO mencatat jumlah penderita HIV/AIDS di dunia meningkat jumlahnya sehingga mencapai 5,2 juta jiwa. Pada tahun 2012 jumlah orang yang terinfeksi terus meningkat pesat dan tersebar luas di seluruh dunia, disebutkan 58 juta jiwa penduduk dunia terinfeksi HIV, 22 juta diantaranya meninggal akibat AIDS. Transmisi HIV masih tetap berlangsung, 16 ribu jiwa terinfeksi baru setiap harinya.

Permasalahan HIV/AIDS tidak hanya terjadi di dunia saja, Indonesia merupakan salah satu negara yang memiliki penderita HIV/AIDS terbesar. Berdasarkan data Kemenkes RI tahun 2014, jumlah kasus HIV tahun 2013 sebesar 29.037 kasus dan AIDS sebesar 5.608 kasus. Dari data tersebut dapat dilihat bahwa masih tingginya angka kejadian HIV/AIDS terutama di Indonesia. Diharapkan kerja sama pemerintah, dinas kesehatan, dukungan sosial baik dari keluarga dan orang-orang di sekitarnya dalam meningkatkan kualitas hidup ODHA.

Permasalahan HIV/AIDS tidak hanya di dunia saja, di Indonesia penyakit AIDS juga mengalami peningkatan yang luar biasa. Penyakit HIV/AIDS dapat membuat kualitas hidup ODHA memburuk karena, penyakit HIV berubah menjadi penyakit kronis, adanya dampak mengkonsumsi obat Anti Retro Viral (ARV) seumur hidup. Kualitas hidup terkait kesehatan menurut WHO meliputi aspek fisik, mental, sosial, dan spiritual/religi, sedangkan yang tidak terkait dengan kesehatan adalah lingkungan dan fisik (Anima, Indonesian Psyhological Journal, 2008). Penelitian yang dilakukan oleh Diatmi (2014) melaporkan dari 76 orang responden ditemukan $58 \%$ ODHA mendapatkan dukungan sosial yang kurang dan 59\% kualitas hidup ODHA rendah. Banyak cara dalam meningkatkan kualitas hidup para ODHA, tetapi Kelompok Dukungan Sebaya (KDS) lebih efektif dilakukan Banyak cara dalam meningkatkan kualitas hidup para ODHA, tetapi Kelompok Dukungan Sebaya (KDS) lebih efektif dilakukan

Pengaruh dukungan kelompok sebaya ODHA akan mempelajari cara hidup bermasyarakat. Kelompok sebaya akan mempengaruhi penanganan sosial ODHA yang baru, misalnya ODHA yang biasa hidup sekitar dapat mengenal kehidupan yang demokratis dalam kelompok sebaya, sehingga didalam kelompok sebaya ODHA mempunyai kesempatan melakukan bermacam macam kelompok sosial. Penelitian yang dilakukan oleh Nuraeni (2011) tentang hubungan dukungan kelompok sebaya dan dukungan keluarga dengan kualitas hidup pada ODHA di Yayasan Akses Indonesia Tasikmalaya, dimana ditemukan masih rendahnya kualitas hidup ODHA yaitu 52,4\%. Dilihat dari hasil deskriptif dukungan kelompok sebaya pada ODHA didapatkan hasil 55,6\% dan dukungan keluarga sebesar $62 \%$. Untuk peningkatan mutu hidup ODHA secara berkesinambungan dan komprehensif perlu dibentuk sistem dukungan sebaya yang lengkap di tingkat propinsi dan di tingkat kabupaten atau kota.

Sumatera Barat merupakan salah satu wilayah yang rentan terhadap penyakit HIV/AIDS, hal ini dibuktikan dengan jumlah kasus HIV/AIDS yang ditemukan yaitu pada tahun 2014 sebanyak 2.088 kasus dengan HIV sebanyak 1.136 kasus dan AIDS sebanyak 952 kasus (Spiritia, 2014). Jumlah pasien HIV/AIDS (ODHA) yang meninggal sebanyak 320 penderita. Sumatera Barat menempati urutan ke 12 setelah Riau. Penderita paling banyak berumur 20-29 tahun. Kota Padang menempati urutan pertama kasus terbanyak HIV/AIDS setelah itu disusul oleh Bukittingi (BPS Sumbar, 2013). Sedangkan di Kota Padang jumlah penderita HIV/AIDS pada tahun 2013 sebanyak 508 orang (Komisi Penanggulangan AIDS Kota Padang, 2013).

Lantera Minangkabau Support merupakan yayasan yang peduli terhadap HIV/AIDS. Lembaga ini memiliki tempat konseling Voluntery Conseling Testing (VCT) sebagai bentuk kegiatan memberikan motivasi pada ODHA. Banyak kegiatan yang dilakukan di Yayasan Lantera Minangkabau Support antara lain advokasi dan loby, networking, peningkatan kapasitas penguatan ke daerah monitoring dan evakuasi, pertemuan koordinasi antara Kelompok Dukungan Sebaya (KDS) sebulan sekali.

Berdasarkan data yang didapat dari Yayasan Lantera Minangkabu Support Padang tahun 2013 terdapat jumlah ODHA sebanyak 975 orang, tahun 2014 sebanyak 1.178 orang. Hasil wawancara yang peneliti lakukan kepada 10 orang ODHA di Yayasan Lantera Minangkabau Support, didapatkan 6 orang ODHA tidak mendapatkan dukungan dari teman sebaya seperti kurang dalam memberikan informasi dalam hal pengobatan ARV dan kegiatan-kegiatan lain yang dapat meningkatkan kualitas hidup ODHA. 4 orang mengatakan teman sebaya saling memberikan dukungan dalam meningkatkan kualitas hidup seperti dalam menjalani pengobatan dan mengikutsertakan disetiap kegiatan social.

\section{METODA PENELITIAN}


Jenis penelitian ini bersifat analitik dengan desain cross sectional study. Penelitian ini telah dilaksanakan di Yayasan Lantera Minangkabau Support Padang pada bulan Februari - Agustus 2016. Populasi adalah seluruh ODHA di Yayasan Lantera Minangkabau Support Padang tahun 2015 yang berjumlah 805 orang dan sampel sebanyak 89 orang diambil dengan Accidental Sampling. Pengolahan data melalui analisa data secara univariat dan bivariat menggunakan Chi-square dengan tingkat kepercayaan $95 \%=0,05$.

\section{HASIL}

\section{A. Analisa Univariat}

Analisis univariat dilakukan untuk melihat distribusi frekuensi dari variabel independent dan variabel dependent, yaitu dukungan kelompok sebaya dan variabel dependent kualitas hidup ODHA di Yayasan Lantera Minangkabau Support Padang Tahun 2016, sebagai mana terlihat pada tabel berikut ini.

1. Kualitas Hidup

Tabel 1. Distribusi Frekuensi Responden Berdasarkan Kualitas Hidup di Yayasan Lantera Minangkabau Support Padang Tahun 2016

\begin{tabular}{|c|c|c|}
\hline Kualitas Hidup & $\mathbf{f}$ & $\%$ \\
\hline Kurang Baik & 37 & 41,6 \\
\hline Baik & 52 & 58,4 \\
\hline Jumlah & 89 & 100 \\
\hline
\end{tabular}

Berdasarkan tabel 4.4 terlihat bahwa dari 89 responden terdapat $37(41,6 \%)$ ODHA memiliki kualias hidup yang kurang baik di Yayasan Lantera Minangkabau Support Padang Tahun 2016.

\section{Dukungan Kelompok Sebaya}

Tabel 2 Distribusi Frekuensi Responden Berdasarkan Dukungan Kelompok Sebaya di Yayasan Lantera Minagkabau Support Padang Tahun 2016

\begin{tabular}{|c|c|c|}
\hline $\begin{array}{c}\text { Dukungan Kelompok } \\
\text { Sebaya }\end{array}$ & $\mathbf{f}$ & $\%$ \\
\hline Kurang Baik & 46 & 51,7 \\
\hline Baik & 43 & 48,3 \\
\hline Jumlah & 89 & 100 \\
\hline
\end{tabular}

Berdasarkan tabel 2 terlihat bahwa dari 89 responden terdapat $46(51,7 \%)$ ODHA mendapatkan dukungan kelompok sebaya yang kurang baik di Yayasan Lantera Minangkabau Support Padang Tahun 2016.

\section{B. Analisis Bivariat}

Hubungan Dukungan Kelompok Sebaya dengan Kualitas Hidup ODHA

Tabel 3 Hubungan Dukungan Kelompok Sebaya (KDS) dengan Kualitas Hidup ODHA di Yayasan Lantera Minangkabau Support Padang Tahun 2016

\begin{tabular}{|c|c|c|c|c|c|c|c|}
\hline \multirow{3}{*}{$\begin{array}{c}\text { Dukungan } \\
\text { Kelompok } \\
\text { Sebaya }\end{array}$} & \multicolumn{4}{|c|}{ Kualitas Hidup } & \multicolumn{2}{|c|}{ Jumlah } & \multirow{2}{*}{$\begin{array}{c}\rho \\
\text { valu } \\
\mathbf{e}\end{array}$} \\
\hline & \multicolumn{2}{|c|}{$\begin{array}{c}\text { Kurang } \\
\text { Baik }\end{array}$} & \multicolumn{2}{|c|}{ Baik } & & & \\
\hline & f & $\%$ & f & $\%$ & f & $\%$ & \\
\hline Kurang & 29 & 63,0 & 17 & 37,0 & 46 & 100 & \\
\hline Baik & & & & & & & 0,000 \\
\hline Baik & 8 & 18,6 & 35 & 81,4 & 43 & 100 & \\
\hline Jumlah & 37 & 41,6 & 52 & 58,4 & 89 & 100 & \\
\hline
\end{tabular}

Berdasarkan tabel 3 terlihat bahwa proporsi ODHA yang memiliki kualitas hidup kurang baik banyak ditemukan pada ODHA yang mendapatkan dukungan kelompok sebaya kurang baik yaitu 29 $(63,0 \%)$ dibandingkan dengan ODHA yang mendapat dukungan kelompok sebaya yang baik yaitu $8(18,6 \%)$. Hasil uji statistik chi-square didapat nilai $\rho$ value $=0,000(\rho<0.05)$ artinya ada hubungan dukungan kelompok sebaya (KDS) dengan kualitas hidup ODHA di Yayasan Lantera Minangkabau Support Padang Tahun 2016.

\section{Pembahasan}

\section{A. Analisi Univariat}

\section{Kualitas Hidup ODHA}

Berdasarkan hasil penelitian yang telah dilakukan, didapatkan bahwa dari 89 responden terdapat 37 (41,6\%) ODHA memiliki kualitas hidup yang kurang baik di Yayasan Lantera Minangkabau Support Padang tahun 2016.

Hasil penelitian hampir sama dengan penelitian yang telah dilakukan oleh Mardhiati (2009) yang melaporkan 30\% mutu hidup ODHA tidak baik di Indonesia. WHO mendefinisikan kualitas hidup sebagai suatu persepsi individu tentang harkat dan martabatnya di dalam konteks budaya dan sistem nilai, yang berhubungan dengan tujuan hidup dan target individu (Ginting, 2009). Kualitas hidup sebagai pandangan atau perasaan seseorang terhadap kemampuan fungsionalnya akibat terserang oleh suatu penyakit. Kualitas hidup ini sangat berkaitan dengan hal-hal yang cukup kompleks seperti kesehatan fisik, kondisi psikologis, tingkat kemandirian, hubungan sosial, dan hubungan 
individu tersebut dengan lingkungannya (Diatmi, dkk, 2014).

Berdasarkan penjelasan diatas, kurang baiknya mutu hidup ODHA terlihat dari hasil jawaban pada kuesioner penelitian, dimana 20,2\% ODHA mengatakan kurang merasa bahagia dalam kehidupannya. Sebesar $15,7 \%$ ODHA mengatakan merasa kehidupannya kurang berarti. Sebesar $12,4 \%$ ODHA mengatakan tidak puas dengan kemampuan yang ditunjukkan dalam aktivitas kehidupan seharihari. Sebesar 70,8\% ODHA mengatakan mengalami perasaan negatif seperti mood yang jelek, merasa cemas atau depresi. Hal ini karena penyakit yang diderita ODHA merupakan penyakit dapat menyebab kematian dan dapat dikucilkan dari lingkungan baik dalam keluarga maupun masyarakat. Selain itu, juga disebabkan oleh kurangnya dukungan dan motivasi yang diberikan keluarga, baik dalam bentuk kedekatan dengan keluarga dan dalam menjalankan kegiatan positif serta adanya kecenderungan ODHA untuk kurang bersosialisasi terhadap lingkungan sekitarnya, sehingga sulit untuk melakukan setiap kegiatan positif.

\section{Dukungan Kelompok Sebaya}

Berdasarkan hasil penelitian yang telah dilakukan, didapatkan bahwa dari 89 responden terdapat $46(51,7 \%)$ ODHA mendapatkan dukungan kelompok sebaya yang kurang baik di Yayasan Lantera Minangkabau Support Padang Tahun 2016.

Hasil penelitian ini sejalan dengan penelitian yang telah dilakukan oleh Diatmi (2014) tentang hubungan dukungan sosial dengan kualitas hidup pada orang dengan HIV dan AIDS (ODHA) di Yayasan Spirit Paramacitta, ditemukan 58\% dukungan sosial yang kurang baik. Penelitian lain yang dilakukan oleh Admila (2014) terhadap 70 orang responden, ditemukan $64,3 \%$ dukungan kelompok sebaya kurang baik.

Dukungan sebaya merupakan dukungan sesama yang dilakukan oleh ODHA atau OHIDHA kepada ODHA dan OHIDHA lainnya, terutama ODHA yang baru mengetahui status HIV (Spiritia, 2011). Kelompok Dukungan sebaya adalah suatu kelompok dimana dua atau lebih orang yang terinteraksi atau terpengaruh oleh HIV berkumpul dan saling mendukung. Dalam suatu kelompok pada awalnya dapat berupa gabungan ODHA dengan latar belakang yang berbeda dan kebutuhan untuk membuat kelompok yang lebih spesifik, seperti kelompok khusus ODHA saja atau dengan latar belakang tertentu atau gabungan ODHA dan OHIDHA.

Peranan utama kelompok dukungan sebaya adalah menciptakan suasana nyaman dan terjaga kerahasiannya, sehingga orang HIV positif mendapatakan kesempatan untuk berkenalan, bicara secara terbuka, didengarkan dan mendapatkan dukungan. Dalam kelompok dukungan, tidak ada yang salah atau yang benar. Tidak ada yang lebih tinggi maupun yang lebih rendah dari yang lainnya.
Dalam kelompok dukungan, para anggota didorong untuk merenungkan diri, dan belajar dari diri sendiri serta orang lain.

Berdasarkan penjelasan diatas, lebih dari separoh dukungan kelompok sebaya kurang baik. Berdasarkan jawaban kuesioner penelitian, dimana $79,8 \%$ mengatakan kelompok sebaya tidak mendukung ODHA dalam melakukan hobi. Hal ini disebabkan oleh hobi setiap ODHA berbeda-beda dan tidak selalu ODHA dapat hadir disetiap kelompoknya. Selain itu, juga disebabkan oleh adanya dari beberapa ODHA yang bersikap introfer (penyendiri atau kurang peduli dengan dunia luar) sehingga orang lain tidak mengetahui tentang status kesehatannya yang menderita HIV/AIDS. Penyebab lain yang membuat dukungan kelompok sebaya kurang baik adalah faktor pekerjaan dari masingmasing ODHA, dimana ditemukan 76,4\% ODHA tidak bekerja. Agar dukungan kelompok sebaya antara sesama ODHA berjalan baik, maka sebaiknya ODHA untuk selalu hadir dalam kelompok baik dalam setiap kegiatan yang dilakukan sesama ODHA maupun di luar Yayasan Lantera Minangkabau Support Padang.

\section{B. AnAliSis Bivariat}

\section{Hubungan Dukungan Kelompok Sebaya dengan Kualitas Hidup ODHA}

Berdasarkan hasil penelitian yang telah dilakukan, didapatkan bahwa proporsi ODHA yang memiliki kualitas hidup kurang baik banyak ditemukan pada ODHA yang mendapatkan dukungan kelompok sebaya kurang baik yaitu $29(63,0 \%)$ dibandingkan dengan ODHA yang mendapat dukungan kelompok sebaya yang baik yaitu 8 $(18,6 \%)$. Hasil uji statistik chi-square didapat nilai $\rho$ value $=0,000(\rho<0.05)$ artinya ada hubungan dukungan kelompok sebaya (KDS) dengan kualitas hidup ODHA di Yayasan Lantera Minangkabau Support Padang Tahun 2016.

Hasil penelitian ini sejalan dengan penelitian Diatmi (2014) tentang hubungan dukungan sosial dengan kualitas hidup pada orang dengan HIV dan AIDS (ODHA) di Yayasan Spirit Paramacitta, ditemukan adanya hubungan dukungan sosial dengan kualitas hidup ODHA ( $\mathrm{p}=0,000)$.

Pengaruh dukungan kelompok sebaya ODHA akan mempelajari cara hidup bermasyarakat. Kelompok sebaya akan mempengaruhi penanganan sosial ODHA yang baru, misalnya ODHA yang biasa hidup sekitar dapat mengenal kehidupan yang demokratis dalam kelompok sebaya, sehingga didalam kelompok sebaya ODHA mempunyai kesempatan melakukan bermacam macam kelompok sosial (Nuraeni, 2011).

Dalam kelompok dukungan, tidak ada yang salah atau yang benar. Tidak ada yang lebih tinggi maupun yang lebih rendah dari yang lainnya. Dalam kelompok dukungan, para anggota didorong untuk 
merenungkan diri, dan belajar dari diri sendiri serta orang lain. Sehingga apabila kelompok dukungan sebaya tidak ada diantara ODHA, maka suasana nyaman, saling bercerita sesama ODHA tidak dapat berjalan dengan baik dan akan berdampak terhadap kualitas hidup masing-masing ODHA. Kualitas hidup ini sangat berkaitan dengan hal-hal yang cukup kompleks seperti fisik, psikologi, sosial dan lingkungan.

Hampir setiap orang tidak mampu menyelesaikan sendiri pekerjaan sendiri mereka memerlukan bantuan orang lain. Berdasarkan hasil penelitian bahwa dukungan kelompok sebaya merupakan mediator yang penting dalam menyelesaikan masalah seseorang. Hal ini karena individu merupakan bagian dari keluarga, teman sekolah atau kerja, kegiatan agama atau pun bagian dari kelompok lainnya (Nursalam \& Kurniawati, 2012).

Asumsi peneliti, terdapat hubungan antara dukungan kelompok sebaya dengan kualitas hidup ODHA karena ODHA yang mendapatkan dukungan kelompok sebaya yang tidak baik akan mempengaruhi terhadap kualitas hidupnya, hal ini dikuatkan dari pertanyaan yang ada dikuesioner dimana $18 \%$ ODHA mengatakan tidak puas dengan dukungan yang didapatkan dari teman-teman. Pengaruh dukungan kelompok sebaya ODHA akan mempengaruhi cara hidup bermasyarakat sehingga ODHA akan menjadi manusia yang lebih percaya diri dan memiliki informasi yang lebih luas dalam menjalani kehidupannya dalam bermasyarakat dimana statusnya sebagai penderita HIV/AIDS.

\section{KESIMPULAN}

Setelah dilakukan penelitian pada 89 orang responden tentang Hubungan Dukungan Kelompok Sebaya dengan Kualitas Hidup ODHA di Yayasan Lantera Minangkabau, maka dapat disimpulkan : Kurang dari separoh $(41,6 \%)$ ODHA memiliki kualias hidup yang kurang baik di Yayasan Lantera Minangkabau Support Padang Tahun 2016. Lebih dari separoh $(51,7 \%)$ ODHA mendapatkan dukungan kelompok sebaya yang kurang baik di Yayasan Lantera Minangkabau Support Padang Tahun 2016. Ada hubungan dukungan kelompok sebaya (KDS) dengan kualitas hidup ODHA di Yayasan Lantera
Minangkabau Support Padang Tahun 2016 ( $\mathrm{p}$ value = 0,000). Diharapkan kepada LSM Yayasan Lantera Minangkabau untuk dapat bekerja sama dengan Dinas Sosial dalam upaya memberikan pembinaan kepada ODHA dan memberikan setiap kegiatan positif yang dapat menciptakan hubungan yang baik sesama ODHA.

\section{DAFTAR PUSTAKA}

[1] Admila. 2014. Hubungan Dukungan Kelompok Sebaya Dengan Respon Emosional pada ODHA di Yayasan Lentera Minangkabau. Skripsi Stikes Alifah Padang

[2] Diatmi dkk. 2014. Hubungan dukungan sosial dengan kualitas hidup pada orang dengan HIV dan AIDS (ODHA) di Yayasan Spirit Paramacitta. Jurnal Psikologi Program Studi Psikologi, Fakultas Psikologi, Universitas Udayana

[3] Ginting, Daniel. 2009. Hubungan Konstruk Kepemimpinan Dengan Kualitas Hidup Penderita HIV/AIDS di Rumah Sakit Rujukan Provinsi Sumatera Utara. Disertasi Fakultas Kedokteran Universitas Sumatera Utara

[4] Hidayat, Aziz, Alimul. 2009. Metode Penelitian Keperawatan dan Teknik Analisis Data. Jakarta : Salemba Medika

[5] Komisi Penanggulangan AIDS Kota Padang, 2013

[6] Notoatmodjo, Soekidjo. 2010. Metodologi Penelitian Kesehatan. Jakarta: Rineka Cipta

[7] Nuraeni. 2011. Hubungan Dukungan Kelompok Sebaya dan Dukungan Keluarga dengan Kualitas Hidup pada ODHA di Yayasan Akses Indonesia Tasikmalaya

[8] Nursalam \& Kurniawati, 2013. Asuhan Keperawatan pada Pasien Terinfeksi HIV/AIDS. Jakarta: Salemba Medika

[9] Spririta, 2011. Penelitian Peran Dukungan Sebaya Terhadap Peningkatan Mutu Hidup ODHA di Indonesia. Jakarta: Yayasan Spiritia

[10] Spririta, 2011. Lembaran Informasi Sejarah HIV/AIDS di dunia. Jakarta: Yayasan Spiritia

[11] Spiritia, 2014. Statistik Kasus HIV/AIDS di Indonesia. Jakarta: Yayasan Spiritia

[12] WHO, 2012. Hidup Bersama HIV/AIDS 